\title{
Health and limitations in health as the determinant of human capital effectiveness: perspective of the EU Member States
}

\author{
Agnieszka Jakubowska \\ Koszalin University of Technology \\ Poland \\ agnieszka.jakubowska@tu.koszalin.pl
}

\begin{abstract}
The purpose of the present article is to indicate and assess the significance of health in the creation of human capital effectiveness. The conducted review was based on the chief theoretical conceptions that describe the impact of health on human capital effectiveness. In the empirical part of the attempt to define the relationship between health, in particular its absence, and the efficiency of human capital measured by human capital indicators (employment) and human capital management quality (income). An assessment was made of the diversification level of the individual variables that describe human capital effectiveness. Unemployment rates and poverty risks were compared between those with health problems and those who are not suffering from health problems, in select EU economies.
\end{abstract}

Keywords: Health, Health Capital, Human Capital, Effectiveness

JEL classification: I14, I15, J24

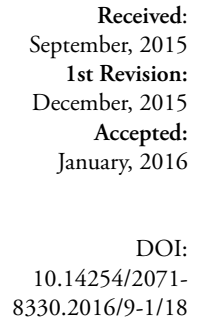

Received: September, 2015 1st Revision: December, 2015 Accepted: January, 2016

DOI: $10.14254 / 2071-$ $8330.2016 / 9-1 / 18$

\section{INTRODUCTION}

Over the last several dozen years, an increase has been observed in the total productivity of manufacturing factors, on the level of both national and regional economies. In the literature, the theories and empirical research of the subject look for the causes of this increase, including education, nutrition and health. They disclose essential relationships between the level of incomes and the level of education, health conditions and nutrition which are observed both on the level of the whole economy (Schultz 1961, Kuntats 1966, Barro i Sala- i-Martin 1995) and on the level of individuals. According to some researchers, it is the scope of health and education that will lead to a decrease in developmental disproportions in the near future between countries with various levels of income (Schultz, 1993).

Investments of time and resources in the creation of human capital contribute to an increase in labourers' production potential, which consequently increases the potential incomes and consumption capacity of labourers for the rest of their lives. The literature aims to define production benefits from time and resource investments that are aimed at raising society's health, and these benefits confirm the existence of an added correlation between investments in health and access to medical care, and those indices that measure economic development and growth. However, impediments that occur when comparing health conditions between the populations of individual countries, regions, areas (a city, country) or social classes (the rich 
and the poor), should be taken into consideration. Those impediments result from both the diversification in access to medical care and the method by which health problems are reported. The existence of an attractive system of social insurances in a given country may encourage one to withdraw from the labour market.

The purpose of the present article is to indicate and assess the significance of health in the creation of potential and real human capital productivity. The research methodology used was adapted to the following accepted assumptions:

- The health potential determines, in a fundamental manner, the human capital productivity with reference to the educational possibilities of disabled people, the ability to effectively use this capital in the labour market, and the incomes which are likely to be gained with this capital.

- In spite of the policy aimed at limiting inequalities and the exclusion of disabled people, there are still great differences between the individual EU Member States in the impact of health limitations on human capital productivity, measured with the degree of access to education and the labour market, the level of "employability" and unemployment, and the probability of poverty and exclusion.

- Those national EU economies can be determined by examining the relative position of people with specific health problems in relation to those who do not suffer from health problems, taking into consideration a detailed assessment criterion.

The conducted review was based on the chief theoretical conceptions that describe the impact of health resources on human capital effectiveness. In the empirical part of the attempt to define the relationship between health, in particular its absence, and the efficiency of human capital measured by human capital indicators (employment) and human capital management quality (income). An assessment was made of the diversification level of the individual variables that describe the phenomenon examined - positioning of select EU economies was made, by examining the unemployment rate and the poverty risk of those with health problems as compared to those who are not suffering from health problems. The fundamental sources of information included Eurostat statistical data processed on the level of national economies. As a consequence, this allowed the author to depict the phenomenon examined in the context of the diversification between the individual EU Member States.

\section{DEMAND FOR HEALTH}

We may find a number of theoretical concepts in the literature suggesting that health should be perceived as one of the forms of human capital (Mushkin 1962, Becker 1964, Fuchs 1996). Consequently, expenses connected with health care and the improvement of its quality - both from the individual (private) and from the state (public) - should be treated as expenditures incurred in order to raise the productivity of the manufacturing factor, i.e. the human capital. This approach can be found in the definition proposed by G. S. Becker, who equated investments in human capital with those activities which, through an increase in human resources, exert an influence on the future income that this resource will be able to generate (Becker 1964).

The so-called conception of "capabilities", which was created by A. Sen (1993) and M. Nussbaum (2000) and then developed by many other authors, is oriented towards a wide definition of human capital taking into consideration bio- and psychophysical components. According to this approach, human capital and an individual's quality of life should be analysed taking into consideration such properties as: life expectancy, appropriate nutrition, appropriate living conditions, general physical and psychical well-being and physical fitness (Nussbaum 2000, Anand 2005). 
Human capital effectiveness as a derivative of expenditures connected with health care and an improvement of physical and psychical condition was developed by M. Grossman, who created a demand model for the commodity known as "health" (Grossman 1972). This model was based on the conception of the socalled "capital of health" as a resource which, besides the potential of knowledge and abilities, determines in a fundamental manner the possibility to gain income by its owner. Grossman's conception assumes that the "health capital" is different from other forms of human capital. In particular, he claims that while knowledge resources have an influence on human capital productivity, the health resource determines the total quantity of time which a human can spend at work. As a consequence, health as a capital resource that produces an effect known as "healthy time" requires an investment of specified expenditures, and it is people who define their optimal level of health as a result of their decisions taken concerning consumption and leisure time.

\section{HEALTH IN ECONOMIC GROWTH MODELS}

For a long period of time, economic growth theories omitted society's health as a factor that determines the effectiveness of macroeconomic-level processes, while assuming that it was of marginal significance. The renaissance of theoretical and empirical research into the causes of economic growth, which has been observed only since the 1980s, has led to a critical analysis of the current output in this scope. This led to studies on endogenous growth theories, where "labor services" defined as the skills "that are available from a healthy physical body" is mentioned as one of the fundamental factors that determine growth potential (Romer 1990).

At present, the literature widely presents theories that describe mutual relationships between society's health and economic growth (Bloom et al. 2004). The theories assume that the level of economic development is a factor that forms a society's quality of life and expenditures related to the health care system. This in turn exerts a fundamental influence on the condition of society's health, and it constitutes a determinant of productivity both on the level of individual companies and entire economies (WHO, 2001).

In analysing the impact of health on the formation of human capital, it is essential to accept the assumption that the absence of good health has an impact not only on the level of an individual or a household; but on the whole economy. A disease forces a working person (or their minder) to limit the work performed. On the scale of the whole society, this leads to a reduction of the current resources of work in the economy and, as a consequence, this causes a decrease of the global production level. The effects of the reduction of the household income level should additionally be taken into consideration, as it results in limited consumption. Negative economic consequences are additionally deepened by decreased proceeds to the state budget that follow from a reduction of streams that are taxable with an indirect tax (production and sales) and with a direct tax (incomes gained by companies and households). At the same time, an increased demand for transfers paid by the government to households is being observed.

The acceptance of the above-mentioned assessment method of the impact of health, and in particular its absence, on the economic effects forced the researchers of the problem to depart from the conception of perceiving the health care system only from the perspective of the direct costs of a disease. A wide approach to the problem of the influence of the lack of health on the value of the product lost by society constituted the grounds to formulate an overall definition of the so-called indirect disease costs understood as a loss of social well-being following from lost production as a result of temporary absence from work and premature mortality (WHO, 2009). At the same time, the management of society's health care funding began to be equated with the process of allocation of investment funds and with the tool of a stimulation of social and economic development (Suhrcke et al. 2006; Popesko et al. 2015). 


\section{DISABILITY AND ACCESS TO EDUCATION AND LABOUR MARKET}

To demonstrate the influence of health limitations on the formation of human capital potential, the impact of specified physical disability on the level of access to education and labour market in EU Member States was analysed. For the purpose of the analysis, two definitions of disability were accepted in accordance with the Eurostat research methodology:

- Definition 1: People having a basic activity difficulty (such as seeing, hearing, walking, communicating);

- Definition 2: People limited in work activities because of a longstanding health problem and/or a basic activity difficulty (LHPAD).

Taking the above assumptions into consideration, an assessment of the relationship between premature completion of education and unemployment among young people and the occurrence of health limitations was made. Table 1 presents the data that describes the phenomenon, as examined in the group of EU Member States.

Table 1

Those with premature completion of education and training (aged 18-24) and young people (aged 25-34) that were either unemployed or not enrolled in education, by country and type of disability, in 2011, (\%).

\begin{tabular}{|c|c|c|c|c|c|c|c|c|}
\hline \multirow{3}{*}{$\begin{array}{l}\text { GEO/type of } \\
\text { disability }\end{array}$} & \multicolumn{4}{|c|}{$\begin{array}{l}\text { Premature finishers of education and training } \\
\text { (age group 18-24) }\end{array}$} & \multicolumn{4}{|c|}{$\begin{array}{l}\text { Young people neither in employment nor } \\
\text { in education and training (age group 25-34) }\end{array}$} \\
\hline & \multicolumn{2}{|c|}{$\begin{array}{l}\text { Difficulty with basic } \\
\text { activities (def. 1) }\end{array}$} & \multicolumn{2}{|c|}{$\begin{array}{l}\text { Limitation in work } \\
\text { caused by a health } \\
\text { condition or difficulty } \\
\text { with a basic activity } \\
\text { (def. } 2 \text { ) }\end{array}$} & \multicolumn{2}{|c|}{$\begin{array}{l}\text { Difficulty with basic } \\
\text { activities (def. 1) }\end{array}$} & \multicolumn{2}{|c|}{$\begin{array}{l}\text { Limitation in work } \\
\text { caused by a health } \\
\text { condition or difficulty } \\
\text { with a basic activity } \\
\text { (def. } 2 \text { ) }\end{array}$} \\
\hline & Yes & No & Yes & No & Yes & No & Yes & No \\
\hline 1 & 2 & 3 & 4 & 5 & 6 & 7 & 8 & 9 \\
\hline EU ( 28 countries $)$ & 25,1 & 12,4 & 31,5 & 12,3 & 34,8 & 18,5 & 44,8 & 18,2 \\
\hline Belgium & 23,9 & 10,4 & 40,7 & 9,9 & 41,0 & 13,6 & 55,0 & 12,7 \\
\hline Bulgaria & 61,1 & 11,0 & 73,2 & 11,0 & 72,9 & 27,4 & 87,9 & 27,1 \\
\hline Czech Rep. & 27,7 & 4,7 & 34,2 & 4,3 & 48,1 & 20,1 & 52,9 & 19,4 \\
\hline Denmark & 16,9 & 8,3 & 20,1 & 7,9 & 32,6 & 8,5 & 37,4 & 7,0 \\
\hline Germany & 19,2 & 10,4 & 41,7 & 10,1 & 27,3 & 16,1 & 50,0 & 15,9 \\
\hline Estonia* & $:$ & 10,4 & $:$ & 10,4 & 37,1 & 19,7 & 53 & 19,1 \\
\hline Ireland & 27,7 & 10,1 & 33,9 & 9,9 & 54,6 & 24,6 & 69,6 & 23,6 \\
\hline Greece & 39,2 & 12,6 & 41,2 & 12,7 & 59,7 & 29,0 & 67,4 & 28,8 \\
\hline Spain & 43,2 & 25,2 & 42,0 & 25,1 & 33,6 & 23,2 & 42,5 & 22,7 \\
\hline France* & 21,4 & 10,1 & $:$ & 10,1 & 27,7 & 16,3 & 30,4 & 15,5 \\
\hline Croatia* & : & 3,4 & $:$ & 3,5 & 54 & 22,3 & 55,7 & 22,6 \\
\hline Italy & 38,4 & 17,2 & 37,9 & 17,3 & 38,0 & 25,1 & 48,2 & 24,9 \\
\hline Cyprus & 27,9 & 10,2 & 27,4 & 10,2 & 41,4 & 13,4 & 41,1 & 13,2 \\
\hline Latvia* & $:$ & 13,2 & $:$ & 13,6 & 38,5 & 23,9 & 49,2 & 23,6 \\
\hline Lithuania & 44,2 & 6,5 & 47,7 & 6,7 & 62,6 & 19,2 & 77,8 & 19,0 \\
\hline Luxembourg* & $:$ & 5,5 & $:$ & 5,4 & 11,9 & 9,5 & 20,4 & 8,8 \\
\hline Hungary & 46,8 & 10,1 & 44,1 & 10,2 & 59,1 & 24,2 & 65,4 & 24,0 \\
\hline Malta* & $:$ & 22,5 & $:$ & 22,0 & : & 17,0 & $:$ & 16,5 \\
\hline Netherlands & 25,8 & 7,5 & 26,5 & 7,5 & 40,0 & 6,9 & 42,1 & 6,7 \\
\hline Austria* & 18,8 & 7,8 & $:$ & 8,5 & 15,9 & 9,6 & 26,7 & 9,3 \\
\hline
\end{tabular}




\begin{tabular}{|c|c|c|c|c|c|c|c|c|}
\hline 1 & 2 & 3 & 4 & 5 & 6 & 7 & 8 & 9 \\
\hline Poland & 27,4 & 4,9 & 26,1 & 5,0 & 53,5 & 18,9 & 60,3 & 18,9 \\
\hline Portugal & 35,5 & 22,9 & 38,4 & 22,6 & 30,0 & 13,2 & 29,7 & 12,9 \\
\hline Romania & 59,5 & 17,4 & 71,3 & 17,3 & 61,0 & 20,2 & 73,6 & 20,1 \\
\hline Slovenia* & $:$ & 3,1 & : & 3,2 & 29,4 & 10,3 & 25,5 & 9,9 \\
\hline Slovakia & 26,8 & 4,8 & 27,4 & 4,7 & 72,2 & 24,8 & 72,6 & 24,4 \\
\hline Finland & 18,9 & 8,0 & 16,4 & 8,3 & 20,2 & 12,0 & 24,1 & 11,7 \\
\hline Sweden & 10,8 & 4,6 & 9,9 & 4,7 & 13,9 & 6,4 & 17,1 & 5,9 \\
\hline UK & 25,3 & 15,1 & 31,9 & 14,7 & 39,8 & 15,3 & 51,7 & 14,7 \\
\hline
\end{tabular}

*Special value: not available

Source: own study based on the data from Eurostat, http://ec.europa.eu/eurostat/, Access: 04.05.2015

The data presented in Table 1 exhibits significant differences in relation to the premature completion of education and unemployment of young people who possess specific limitations in health. On the scale of the whole European Union, the index of the premature completion of education among people having a basic activity difficulty (def. 1) is almost 13 percentage points higher than in the group of people who have no health problems. In the case of people with limitations in their work activities because of a longstanding health problem and/or a basic activity difficulty (def. 2), this difference is over 19 percentage points. This indicates existing barriers in access to education for people with health problems. Consequently, this determines a lower quality of work resources for this group at the very start.

An analysis of data related to the possibility to find employment also demonstrated significant difficulties in this area for people with a specific degree of disability. The interest of young people (aged 25-34) who are not employed or enrolled in any education is higher by 16.3 percentage points in the first group of disabled people (def. 1), and in the second group, it is respectively higher by 26.6 percentage points (def. 2) relative to those without any limitations in health. From among the states examined, Bulgaria is characterized by the highest disproportions in access to education and to the labour market due to health limitations, while the smallest differences in this area were observed in Sweden. Figure 1 presents differences in the index levels examined for the European Union (the average) and for selected countries.

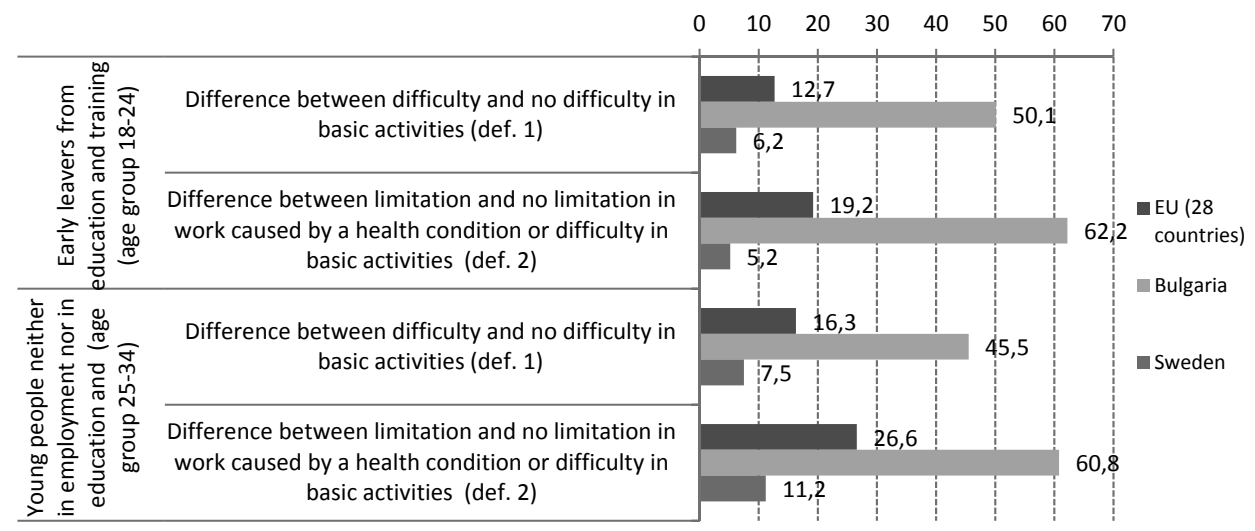

Figure 1. The differences in the index levels examined for the European Union (the average) and for selected countries, in 2011.

Source: own study based on the data from Eurostat, http://ec.europa.eu/eurostat, Access: 04.05.2015. 
A high level of diversification of the situation for the disabled in the group of EU Member States, in terms of both access to education and employment, is confirmed by the analysis of both the gap and the changeability coefficient of the indices observed for both selected groups of people with health limitations. Table 2 presents selected statistical data that describes the diversification level of the parameters examined in a group of the EU Member States.

Table 2

Selected statistics for the EU Member States (in 2011)

\begin{tabular}{|l|c|c|c|c|c|c|}
\hline \multicolumn{1}{|c|}{ Specification } & Average & Interval & Min. & Max. & $\begin{array}{c}\text { Standard } \\
\text { deviation }\end{array}$ & $\begin{array}{c}\text { Coefficient } \\
\text { of variation }\end{array}$ \\
\hline $\begin{array}{l}\text { Premature finishers of education and } \\
\text { training (age group 18-24), people having } \\
\text { a basic activity difficulty, in \% (def. 1) }\end{array}$ & 31,2 & 50,3 & $\begin{array}{c}10,8 \\
\text { (Sweden) }\end{array}$ & $\begin{array}{c}61,1 \\
\text { (Bulgaria) }\end{array}$ & 13,3 & $43 \%$ \\
\hline $\begin{array}{l}\text { Premature finishers of education and train- } \\
\text { ing (age group 18-24), people limited in } \\
\text { work activity because of a longstanding } \\
\text { health problem and/or a basic activity dif- } \\
\text { ficulty (LHPAD), in \% (def. 2) }\end{array}$ & 36,6 & 63,3 & $\begin{array}{c}9,9 \\
\text { (Sweden) }\end{array}$ & $\begin{array}{c}73,2 \\
\text { (Bulgaria) }\end{array}$ & 15,6 & $43 \%$ \\
\hline $\begin{array}{l}\text { Young people neither employed nor en- } \\
\text { rolled in education and training (age group } \\
\text { 25-34), people having a basic activity } \\
\text { difficulty, in \% (def. 1) }\end{array}$ & 41,3 & 61,0 & $\begin{array}{c}11,9 \\
\text { (Luxembourg) }\end{array}$ & $\begin{array}{c}72,9 \\
\text { (Bulgaria) }\end{array}$ & 17,0 & $41 \%$ \\
\hline $\begin{array}{l}\text { Young people neither employed nor en- } \\
\text { rolled in education and training (age group } \\
\text { 25-34), people limited in work activity } \\
\text { because of a longstanding health problem } \\
\text { and/or a basic activity difficulty (LHPAD), } \\
\text { in \% (def. 2) }\end{array}$ & 49,2 & 70,8 & $\begin{array}{c}17,1 \\
\text { (Sweden) }\end{array}$ & $\begin{array}{c}87,9 \\
\text { (Bulgaria) }\end{array}$ & 18,9 & $38 \%$ \\
\hline
\end{tabular}

Source: own study based on the data from Eurostat, http://ec.europa.eu/eurostat/, Access: 04.05.2015.

\section{EMPLOYMENT, UNEMPLOYMENT AND RISK OF POVERTY}

The effect of human capital on production processes in the economy that occurs and the possibility to generate income from the added value gained is a fundamental indicator of human capital productivity. In order to assess the impact of health limitations on the level of human capital use in the EU Member States, a comparison was made between employment and unemployment rates observed among healthy and disabled people using the definitions presented above. Table 3 presents characteristics that describe the phenomenon examined in a group of the EU Member States.

An analysis of the index of "employability" of labour resources with basic activity difficulties (def. 1) shows that in the year 2011 in the EU Member States, it was on average lower by almost 20 percentage points $(47.3 \%)$ than the analogous level with people without such problems (66.9\%). On the level of national labour markets, the highest inequalities in employment rates between the groups examined occurred in the Netherlands ( $42.7 \%$ and $80.1 \%$ respectively) and in Hungary $(23.7 \%$ and $61 \%$ ), where the differences observed amounted to over 37 percentage points. The smallest inequalities between the levels of "employability" of people from both groups were noted in Luxemburg, where the difference between the levels of the indices was only 2.5 percentage points. 
Employment and unemployment rates among healthy and disabled people in a group of the EU Member States (in 2011)

\begin{tabular}{|c|c|c|c|c|c|c|c|c|}
\hline & \multicolumn{4}{|c|}{ Employment rate } & \multicolumn{4}{|c|}{ Unemployment rate } \\
\hline & \multicolumn{2}{|c|}{$\begin{array}{l}\text { Difficulty with basic } \\
\text { activities (def. 1) }\end{array}$} & \multicolumn{2}{|c|}{$\begin{array}{l}\text { Limitation in work } \\
\text { caused by a health } \\
\text { condition or difficulty } \\
\text { with a basic activity } \\
\text { (def. } 2 \text { ) }\end{array}$} & \multicolumn{2}{|c|}{$\begin{array}{l}\text { Difficulty with basic } \\
\text { activities (def. 1) }\end{array}$} & \multicolumn{2}{|c|}{$\begin{array}{l}\text { Limitation in work } \\
\text { caused by a health } \\
\text { condition or difficulty } \\
\text { with a basic activity } \\
\text { (def. } 2 \text { ) }\end{array}$} \\
\hline & Yes & No & Yes & No & Yes & No & Yes & No \\
\hline EU (28 countries) & 47,3 & 66,9 & 38,1 & 67,7 & 12,1 & 9,6 & 17,4 & 9,4 \\
\hline Belgium & 40,7 & 66,4 & 33,4 & 67,3 & 10,1 & 6,1 & 13,8 & 5,8 \\
\hline Bulgaria & 30,7 & 61,8 & 17,8 & 62,1 & 14,3 & 11,2 & 21,7 & 11,1 \\
\hline Czech Republic & 38,6 & 68,5 & 34,5 & 69,3 & 15,7 & 6,3 & 21,0 & 5,9 \\
\hline Denmark & 46,7 & 78,1 & 41,4 & 80,0 & 10,8 & 7,1 & 13,2 & 6,8 \\
\hline Germany & 51,5 & 72,1 & 35,8 & 72,4 & 12,2 & 6,4 & 21,7 & 6,1 \\
\hline Estonia & 49,5 & 68,6 & 33,6 & 70,4 & 18,4 & 11,5 & 27,2 & 11,1 \\
\hline Ireland & 29,8 & 60,9 & 21,6 & 62,2 & 17,9 & 14,8 & 22,9 & 14,6 \\
\hline Greece & 35,5 & 58,5 & 29,8 & 58,9 & 14,6 & 16,7 & 15,5 & 16,6 \\
\hline Spain & 44,3 & 60,5 & 33,8 & 62,0 & 23,3 & 21,9 & 28,2 & 21,6 \\
\hline \begin{tabular}{|l|} 
France \\
\end{tabular} & 56,2 & 66,1 & 59,6 & 68,0 & 12,3 & 8,7 & 20,1 & 7,9 \\
\hline Croatia & 33,0 & 55,8 & 31,6 & 55,0 & 16,3 & 13,6 & 17,6 & 13,6 \\
\hline Italy & 45,6 & 58,9 & 37,0 & 59,4 & 8,1 & 8,0 & 11,4 & 7,8 \\
\hline Cyprus & 46,4 & 70,9 & 41,4 & 71,7 & 10,2 & 7,2 & 11,3 & 7,1 \\
\hline Latvia & 50,8 & 62,6 & 40,7 & 63,1 & 17,5 & 17,4 & 21,5 & 17,1 \\
\hline Lithuania & 40,4 & 63,2 & 32,5 & 63,9 & 23,6 & 15,1 & 26,9 & 15,0 \\
\hline Luxembourg & 62,5 & 64,9 & 48,3 & 67,2 & 4,9 & 5,3 & 8,0 & 4,8 \\
\hline Hungary & 23,7 & 61,1 & 18,1 & 60,9 & 19,4 & 10,3 & 25,0 & 10,2 \\
\hline Malta & 34,4 & 59,2 & 29,9 & 60,5 & $:$ & 7,3 & $:$ & 7,1 \\
\hline Netherlands & 42,7 & 80,1 & 39,4 & 80,4 & 8,6 & 4,1 & 9,5 & 4,0 \\
\hline Austria & 60,3 & 75,6 & 48,2 & 76,4 & 6,0 & 3,8 & 7,9 & 3,8 \\
\hline \begin{tabular}{|l|} 
Poland \\
\end{tabular} & 33,9 & 63,9 & 26,2 & 63,9 & 11,5 & 9,4 & 14,9 & 9,3 \\
\hline Portugal & 51,0 & 67,8 & 44,0 & 69,6 & 14,4 & 12,5 & 16,4 & 12,2 \\
\hline Romania & 31,8 & 63,5 & 23,9 & 64,8 & 8,1 & 7,5 & 9,1 & 7,4 \\
\hline Slovenia & 47,0 & 68,4 & 43,9 & 70,3 & 9,9 & 7,5 & 11,7 & 7,1 \\
\hline Slovakia & 31,9 & 62,6 & 29,2 & 63,4 & 19,0 & 12,9 & 21,6 & 12,7 \\
\hline Finland & 60,8 & 73,2 & 50,6 & 74,8 & 9,1 & 7,5 & 10,9 & 7,4 \\
\hline Sweden & 66,2 & 75,7 & 61,5 & 76,6 & 9,6 & 7,3 & 11,4 & 7,0 \\
\hline United Kingdom & 47,6 & 75,4 & 36,0 & 76,0 & 10,6 & 7,9 & 15,0 & 7,6 \\
\hline
\end{tabular}

Source: own study based on the data from Eurostat, http://ec.europa.eu/eurostat, Access: 04.05.2015.

Analogically, the index of "employability" with people reporting limitations in work activity because of a LHPAD (def. 2) in the EU Member States-28 was on average $38.1 \%$, and it was almost 30 percentage points lower than in the group of healthy people. In this case, too, significant differences between these indices were observed in the individual EU Member States. In the case of Great Britain, Ireland, Romania, the 
Netherlands, Hungary and Bulgaria, these divergences amounted to over 40 percentage points. The smallest difference was observed in France: 8.4 percentage points. Table 4 presents selected statistical data that describes the diversification level of the parameters examined in a group of the EU Member States.

Table 4

Selected statistics for the EU Member States (in 2011)

\begin{tabular}{|l|c|c|c|c|c|c|}
\hline \multicolumn{1}{|c|}{ Specification } & Average & Interval & Min. & Max. & $\begin{array}{c}\text { Standard } \\
\text { deviation }\end{array}$ & $\begin{array}{c}\text { Coefficient } \\
\text { of variation }\end{array}$ \\
\hline $\begin{array}{l}\text { Employment rate, people having a basic } \\
\text { activity difficulty, in \% (def. 1) }\end{array}$ & 44,1 & 42,5 & $\begin{array}{c}23,7 \\
\text { (Hungary) }\end{array}$ & $\begin{array}{c}66,2 \\
\text { (Sweden) }\end{array}$ & 11,0 & $25 \%$ \\
\hline $\begin{array}{l}\text { Employment rate, people limited in work } \\
\text { activity because of a longstanding health } \\
\text { problem and/or a basic activity difficulty } \\
\text { (LHPAD), in \% (def. 2) }\end{array}$ & 36,6 & 43,7 & $\begin{array}{c}17,8 \\
\text { (Bulgaria) }\end{array}$ & $\begin{array}{c}61,5 \\
\text { (Sweden) }\end{array}$ & 10,9 & $30 \%$ \\
\hline $\begin{array}{l}\text { Unemployment rate, people having a basic } \\
\text { activity difficulty, in \% (def. 1) }\end{array}$ & 13,2 & 18,7 & $\begin{array}{c}4,9 \\
\text { (Luxembourg) }\end{array}$ & $\begin{array}{c}23,6 \\
\text { (Lithuania) }\end{array}$ & 5,0 & $38 \%$ \\
\hline $\begin{array}{l}\text { Unemployment rate, people limited in } \\
\text { work activity because of a longstanding } \\
\text { health problem and/or a basic activity dif- } \\
\text { ficulty (LHPAD), in \% (def. 2) }\end{array}$ & 16,9 & 20,3 & $\begin{array}{c}7,9 \\
\text { (Austria) }\end{array}$ & $\begin{array}{c}28,2 \\
\text { (Spain) }\end{array}$ & 6,3 & $37 \%$ \\
\hline
\end{tabular}

Source: own study based on the data from Eurostat, http://ec.europa.eu/eurostat, Access: 04.05.2015.

As mentioned previously, the deprecation level of human capital burdened with a specific degree of disability is also made evident with the level of incomes which it is able to generate on the labour market. In the case of the occurrence of health problems, there are limitations in an effective use of this resource that result both from the idea of the disease but also from a number of factors determined by the environment of a disabled person (including the quality of the social and economic policy of the government and the level of institutional support in the employment of disabled people, as well as the social attitude towards the employment of disabled people). The income condition of people with limitations in health as compared to the rest of the population discloses the scale of discrimination in statistical research, and at the same time it shows a notable degree of the impact of disability on the possibility to gain incomes from work. In order to assess the degree of the integration of labour markets in the EU Member States in the area of disabled people, a comparison was made of those indices that define the percentage of working people with the risk of poverty in the group of disabled people and in the group of people with no such limitations (Fig. 2). At the same time, this Figure presents the overall poverty risk level in both groups examined.

As the results of the analysis indicate, the problem of poverty risk concerns both groups that were examined. Merely undertaking employment does not eliminate this risk entirely. However, in the EU-28, the percentage of working people with health limitations is on average 3 percentage points higher than in the group of people without any limitations; yet, looking at the total population with a specific degree of disability (regardless of the status on the labour market), the risk of poverty grows by above $4 \%$ as compared to healthy people. Starting work by a person with limitations in health reduces the risk of poverty by almost 7.5 percent (average in EU-28). In this case, great divergences are observed between the EU Member States (Table 5). 


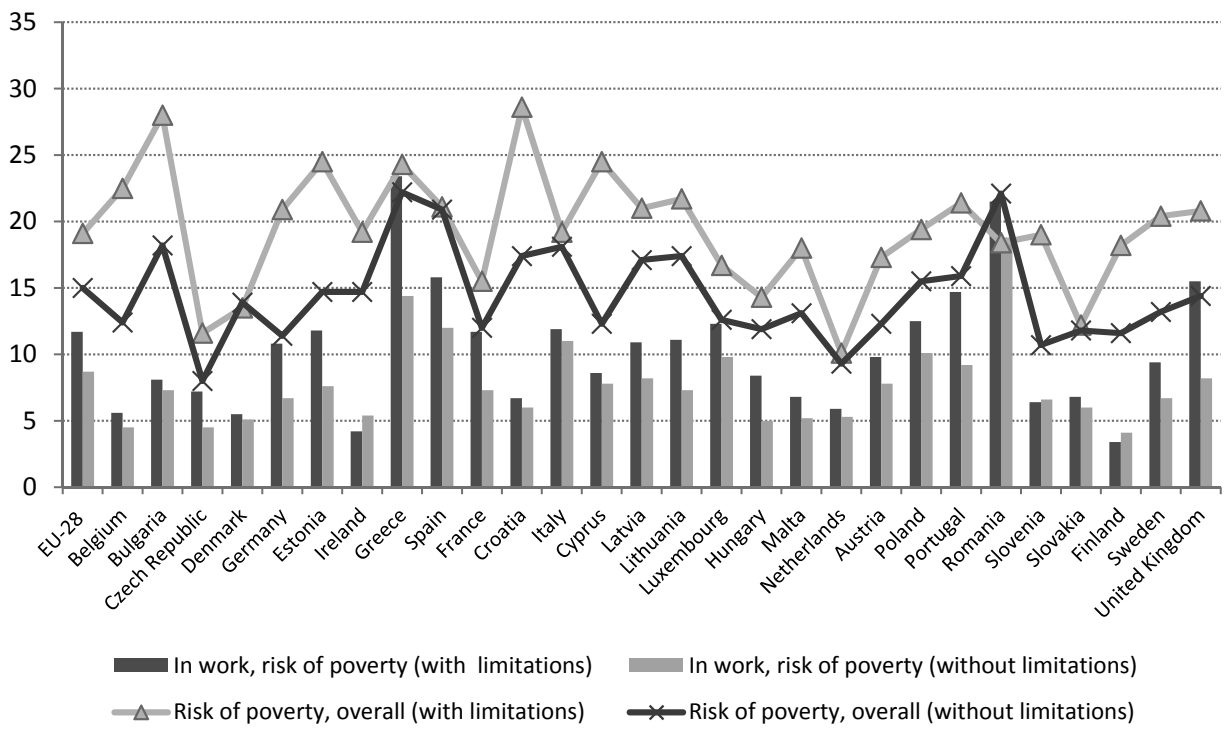

Figure 2. Percentage of people with the risk of poverty in the group of disabled people and in the group of people with no such limitations (of working people and overall)

Source: own study based on the data from Eurostat, http://ec.europa.eu/eurostat, Access: 04.05.2015.

Table 5

Selected statistics for the EU Member States (in 2012)

\begin{tabular}{|l|c|c|c|c|c|c|}
\hline \multicolumn{1}{|c|}{ Specification } & Average & Interval & Minimum & Maksimum & $\begin{array}{c}\text { Standard } \\
\text { deviation }\end{array}$ & $\begin{array}{c}\text { Coefficient } \\
\text { of variation }\end{array}$ \\
\hline $\begin{array}{l}\text { In work, risk of poverty } \\
\text { (with limitations) }\end{array}$ & 10,2 & 20,0 & $\begin{array}{c}3,4 \\
\text { (Finland) }\end{array}$ & $\begin{array}{c}23,4 \\
\text { (Greece) }\end{array}$ & 4,8 & $47 \%$ \\
\hline $\begin{array}{l}\text { In work, risk of poverty } \\
\text { (without limitations) }\end{array}$ & 7,8 & 14,7 & $\begin{array}{c}4,1 \\
\text { (Finland) }\end{array}$ & $\begin{array}{c}18,8 \\
\text { (Romania) }\end{array}$ & 3,2 & $42 \%$ \\
\hline $\begin{array}{l}\text { Risk of poverty, overall } \\
\text { (with limitations) }\end{array}$ & 19,4 & 18,5 & $\begin{array}{c}10,1 \\
\text { (Netherlands) }\end{array}$ & $\begin{array}{c}28,6 \\
\text { (Croatia) }\end{array}$ & 4,5 & $23 \%$ \\
\hline $\begin{array}{l}\text { Risk of poverty, overall } \\
\text { (without limitations) }\end{array}$ & 14,5 & 14,2 & $\begin{array}{c}8,0 \\
\text { (Czech Republic) }\end{array}$ & $\begin{array}{c}22,2 \\
\text { (Greece) }\end{array}$ & 3,6 & $25 \%$ \\
\hline
\end{tabular}

Source: own study based on the data from Eurostat, http://ec.europa.eu/eurostat, Access: 04.05.2015.

In order to determine the specificity of national economies in the area of the depreciation of the human capital value following from health limitations, a ranking was compiled of selected EU states taking into consideration two parameters: the unemployment rate and the level of the "at-risk-of-poverty" index among people with limitations in physical activity (Fig. 3a). Further, an analogous assessment was made based on an examination of the relations between these indices with reference to those quantities that characterize a healthy population (Fig. 3b.). 
a) in nominal data

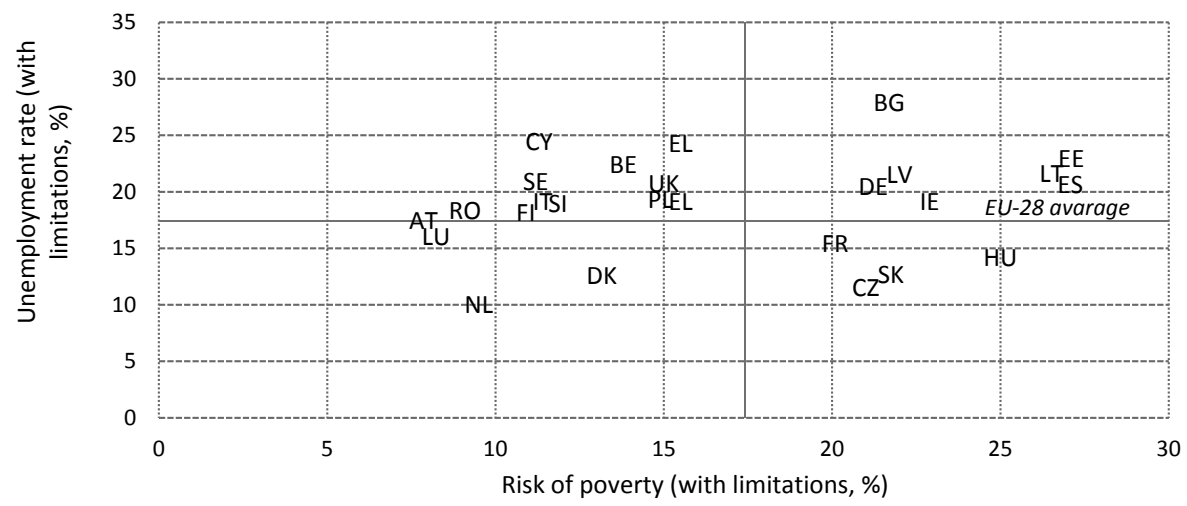

b) with reference to those quantities that characterize a healthy population

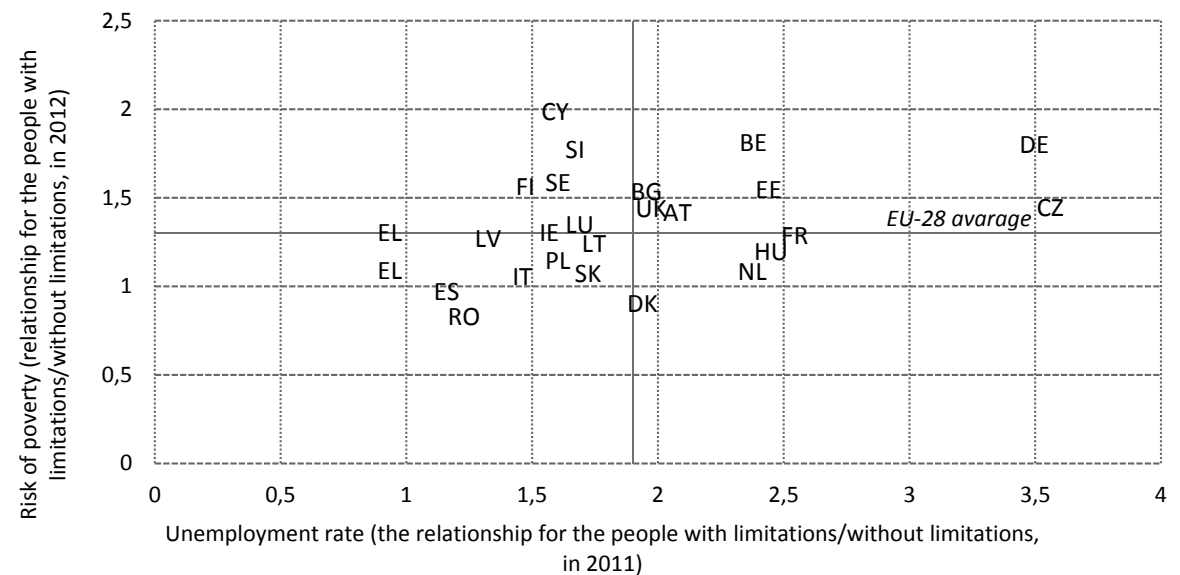

Figure 3. The relationship between the unemployment rate and the level of the "at-risk-of-poverty" index among people with limitations in physical activity, of the EU Member States (in 2011 and 2012) Source: own study based on the data from Eurostat, http://ec.europa.eu/eurostat/, Access: 04.05.2015.

The analysis carried out allowed the author to compile a ranking of the economies of the EU Member States with regard to the degree of impact of disability on the potential of an effective use of labour resources. In the case of the values of the indices (Fig. 3a), countries were selected with the highest unemployment rates and the greatest risks of poverty determined with limitations in health (area in the upper right corner). This included such countries as: Bulgaria, Latvia, Estonia, Lithuania, Spain, Ireland and Germany.

In the case of relative values (the relationship between the index level for disabled people and the index level for healthy people, cf. Fig. 3b), countries were selected with the highest disproportion of the condition of the disabled as compared to people without any limitations in health (area in the upper right corner). This included countries such as: Belgium, Bulgaria, Estonia, United Kingdom, Germany, Austria and Czech Republic. 


\section{CONCLUSIONS}

The multiple impact of this phenomenon constitutes one of the fundamental problems in the measurement of the impact of health on human capital productivity. An increase in productivity human capital expenditures leads to a growth in incomes, and thereby it allows an improvement of both the quality of nutrition and access to health care services. This causes a cumulative effect on the impact of initial expenditures. The problem of the impact of additional expenditures on health in the aspect of the level of social inequalities became the subject itself of separate analyses (Marmot \& Bobak, 2000; Wagstaff \& van Doorslaer, 2000). The health impact of disproportions in incomes and degree of wealth has also become a problem that is more and more frequently perceived, not only by experts, but also by policy-makers (Dahlgren, 2006). In October 2005, the EU Commissioner for Health and Consumer Protection, Markos Kyprianou, highlighted this in his speech at the EU Summit on Tackling Health Inequalities, by stating, "With growing inequalities in wealth have come growing inequalities in health. And in turn inequalities in population health contribute to widening disparities in wealth" (Kyprianou, 2005).

The attempt made in the article to indicate the significance of the absence or rather, from the perspective of the labour market, an insufficient potential of health in the formation of the production capacity of human capital has demonstrated its key significance in the creation of the ability to gain long-term benefits from the human capital resources possessed, even on such potentially integrated and privileged labour markets as those of the EU Member States. A strong diversification demonstrated in those parameters that describe the potential level of the use of human capital with specified limitations in health in the individual EU Member States shows a strong influence of endogenous factors in the formation of regional labour markets.

\section{REFERENCES}

Anand P. (2005), Capabilities and Health, "Journal of Medical Ethics", Vol. 31.

Barro R. and Sala-i-Martin X. (1995), Economic Growth, McGraw Hill, New York.

Becker G. S. (1964), Human Capital, New York: Columbia Univ. Press.

Bloom D., Canning D., Sevilla J. (2004), The effect of health on economic growth: a production function approach, „World development", 32(1), p. 1-13.

Dahlgren G., Whitehead M. (2006), European strategies for tackling social inequities in health: Levelling up Part 2, WHO Collaborating Centre for Policy Research on Social Determinants of Health University of Liverpool, Studies on social and economic determinants of population health, No. 3 .

Fuchs V. R. (1996), Economics, values, and health care reform, „American Economic Review”, Nr 86.1, p. 1-24.

Grossman M. (1972), On the concept of health capital and the demand for health, „The Journal of Political Economy”, no. 2, 223-255.

Kuznets, S. (1966), Modern Economic Growth: Rate, Structure and Spread, Yale University Press, New Haven.

Kyprianou M. (2005), Facing up to health inequalities in Europe, Presentation at EU Summit: Tackling health inequalities: governing for health, London, England, 17-18. October 2005.

Marmot M., Bobak M. (2000), International comparators and poverty and health in Europe, "BMJ: British Medical Journal", 321(7269), p. 1124-1128.

Mushkin S. J. (1962), Health as an Investment, „Journal of Political Economy”, Vol. 70, No. 5, Part 2: Investment in Human Beings, p. 129-157.

Nussbaum M. C. (2000), Women and Human Development: The Capabilities Approach, Cambridge University Press, Cambrige. 
Popesko, B., Novák, P., Papadaki, S. (2015), Measuring diagnosis and patient profitability in healthcare: economics vs ethics, Economics and Sociology, Vol. 8, No 1, pp. 234-245. DOI: 10.14254/2071- 789X.2015/8-1/18

Romer P. (1990), Endogenous technological change, „Journal of Political Economy”, Vol. 98, No. 5, Part 2, p. 71-102.

Schultz T.P. (1993), Investments in the schooling and health of women and men: quantities and return, "Journal of Human Resources", No 28 (4), p. 694-734.

Schultz, T.W. (1961), Investments in human capital, "American Economic Review" 51(1), p. 1-17.

Sen A. (1993), Capability and Wellbeing, (w:) Nussbaum M.C., Sean, A. (eds.), The Quality of Life, Clarendon Press, Oxford.

Suhrcke M., McKee M., Stuckler D., Sauto Arce R., Tsolova S., J. Mortensen (2006), The contribution of health to the economy in the European Union, „Public health”, Nr 120(11), s. 994-1001

Wagstaff A., van Doorslaer E. (2000), Income inequality and health: what does the literature tell us?, "Annual Review of Public Health", Vol. 21.

WHO (2001), Macroeconomics and health: investing in health for economic development, Geneva, World Health Organization, Commission on Macroeconomics and Health. 